\title{
PENENTUAN RUTE DISTRIBUSI PRODUK YANG OPTIMAL DENGAN MENGGUNAKAN CLARKLE AND WRIGHT SAVING HEURISTIK
}

\author{
Heru Winarno ${ }^{1)}$, Samsul Arifin ${ }^{2)}$ \\ Jurusan Teknik Industri, Fakultas Teknik \\ Universitas Serang Raya,Taman Drangong, Serang, Banten, 42111, Indonesia \\ E-mail : heruwinarno42@gmail.com; samsularifin181018@gmail.com
}

\begin{abstract}
A b strak
PT X adalah salah satu perusahaan yang bergerak pada bidang Transportasi, Warehousing, dan Packaging, yang berlokasi di Cilegon Banten. Kegiatan bisnis yang sangat dominan di PT. X adalah pendistribusi barang dari pabrik ke daerah sekitar Banten. Salah satunya barang yang didistribusikan yaitu semen, untuk memenuhi banyaknya permintaan semen dari toko-toko yang tersebar di Banten. Tujuan utama dalam distribusi ini adalah untuk merangcang biaya yang optimal dalam pendistribusian produk dari gudang ke setiap toko. dengan jarak tempuh minimum setiap rute dalam pengiriman dan pendistribusian produknya serta meminimasi total biaya trasportasnyai. Metode yang digunakan dalam kasus ini adalah clarkle wright saving heuristic. Hasil pengolahan data menggunakan metode clarkle wright saving heuristic dengan menempuh jarak Serang sejauh $321 \mathrm{~km}$ dan biaya transportasi Rp.400,000. Jarak daerah Rangkas Bitung rute pertama 178 KM dikeluarkan oleh perusahaan Rp 370,000. Dan rute kedua $203 \mathrm{KM}$ di keluarkan oleh perusahaan $R p$ 370,000. Utuk rute daerah Labuan rute pertama $406 \mathrm{KM}$ di keluarkan oleh perusahaan $R p 560.000$ dan rute ke dua dengan jarak 437 KM di keluarkan perusahaan Rp 600.000.
\end{abstract}

Kata Kunci: Capacitated vehicle routing problem (CVRP), algoritma Clarke and Wright Savings.

\section{PENDAHULUAN}

Distribusi sering kali masih menjadi kendala terbesar terutama bagi perusahaan yang memproduksi secara besar. Distribusi sebagai salah satu instrumen penting dalam dunia perdagangan dimana dengan distribusi yang tepat, maka akan memberikan keuntungan bagi semua pihak. Proses distribusi yang efektif dan efisien menjadi salah satu faktor yang posisinya mulai sejajar dengan indikator-indikator yang lain dalam usahanya untuk mencapai kepuasan pelanggan. Semakin tingginya tingkat persaingan dalam dunia industri, menuntut perusahaan untuk dapat membuat strategi-strategi distribusi yang lebih baik. Salah satu strategi yang dapat digunakan adalah perencanaan dan penentuan rute secara tepat, sehingga produk akan diterima pelanggan dalam jumlah tepat dan biaya yang rendah. Oleh karena itu masalah yang harus dilakukan oleh perusahaan adalah pemilihan rute distribusi yang benar-benar optimal.

Permasalahan routing menyangkut bagaimana mengatur urutan pelanggan akan di datangi dengan berawal dan berakhir pada depot, jika waktu kedatangan dan kepergian juga di tentukan, permasalahan penjadwalan di sini menyangkut pula aspek waktu kunjungan yang selanjutnya aspek ini menjadi sktruktur tambahan pada rute alat angkut. PT X adalah yang bergerak dalam bidang pendistribusian semen. Perusahaan tersebut mempunyai masalah dalam pendistribusian produk ke pelanggan. Perusahaan belum memiliki rute pengiriman ke agen atau toko yang tepat yang bisa memperpendek jarak dan meminimasi biaya transportasi. Permasalahan yang dihadapi oleh perusahaan adalah belum adanya sistem perencanaan pendistribusian barang yang tepat dalam menentukan jalur distribusi ke customer sehingga jarak pengiriman yang ditempuh panjang sehingga mengakibatkan biaya distribusi menjadi mahal. Selain itu, produk dari perusahaan ke customer dan pengoptimalan kendaraan yang digunakan dalam distribusi dinilai sangat penting bagi perusahaan dalam pengoptimalan jumlah barang yang dikirim. Metode penghematan Clarke 
and Wright merupakan suatu medote yang ditemukan oleh Clarke and wright pada tahun 1964 yang kemudian dipublikasikan sebagai algoritma yang digunakan sebagai solusi untuk permasalahan rute kendaraan dimana sekumpulan rute pada setiap langkah ditukar untuk mendapatkan sekumpulan rute yang lebih baik. Inti dari metode ini adalah melakukan perhitungan penghematan yang diukur dari seberapa banyak kemudian dilakukan pengurangan jarak tempuh dan waktu yang digunakan dengan mengaitkan node-node yang ada dan menjadikannya sebuah rute berdasarkan nilai saving yang terbesar yaitu jarak tempuh antara source node dan note tujuan. (Bowersox, DJ, 2002)

Metode penghematan ini merupakan prosedur pertukaran yaitu bahwa sekumpulan rute pada setiap langkah ditukar untuk mendapatkan sekumpulan rute yang lebih baik. Pada awalnya, diasumsikan bahwa setiap titik permintaan dipenuhi secara individual oleh suatu kendaraan yang terpisah, sebagai gambaran, missal terdapat dua node y dan $\mathrm{z}$ membentuk rute tersendiri dan dilayani kendaraan yang berbeda. Jika digunakan satu kendaraan sebagai pengganti dua kendaraan untuk melayani node y dan z, maka akan diperoleh penghematan Syz berupa jarak tempuh. Dalam hal ini node y dan $\mathrm{z}$ membentuk rute dan dilayani oleh kendaraan yang sama.untuk menentukan rute awal.

\section{METODE PENELITIAN}

Langkah-langkah dalam pemecahan masalah penelitian ini di sajikan pada gambar 1 dibawah ini :

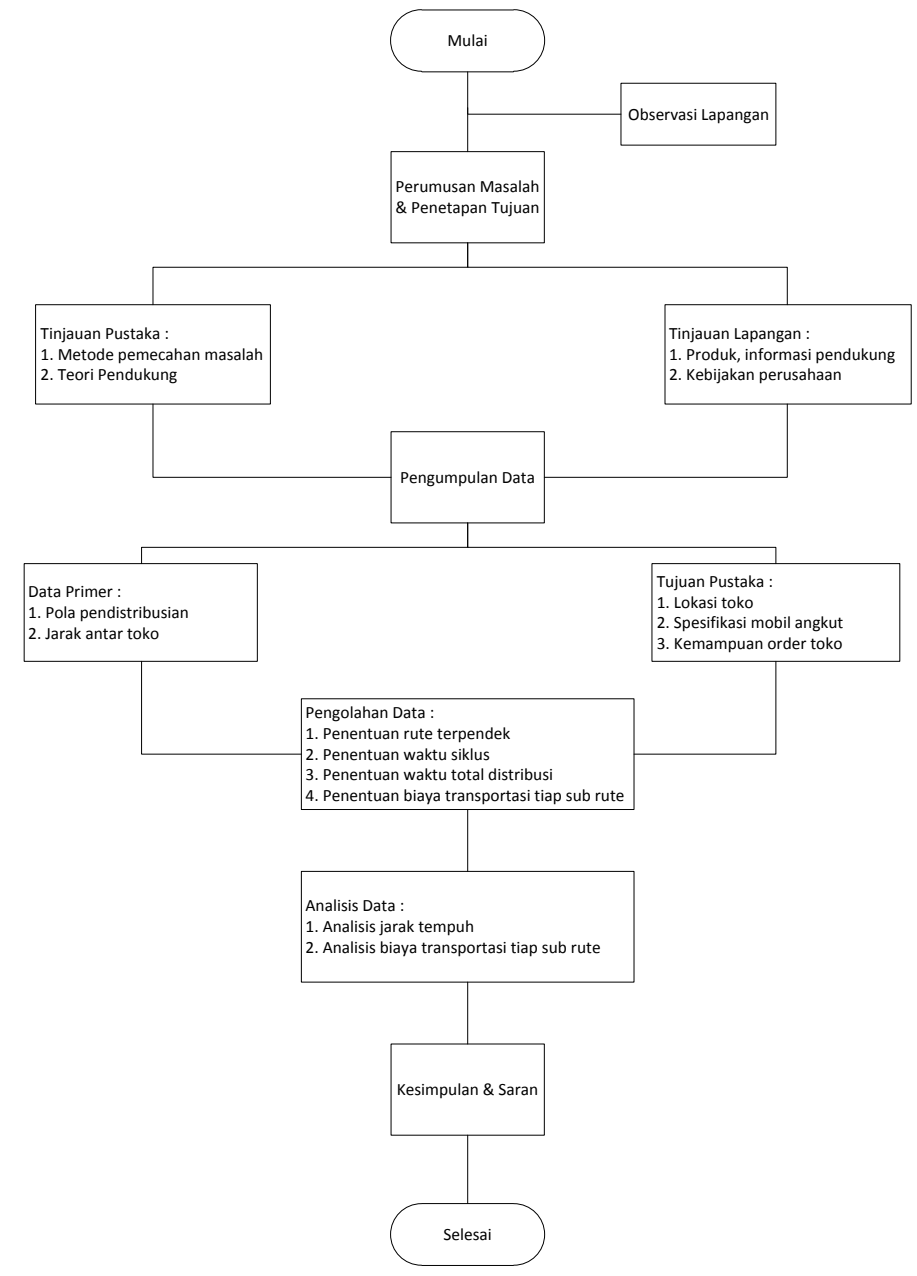

Gambar 1. Flow chart Pemecahan Masalah 
Algoritma Metode Clark and Wright Saving Heuristic untuk menyelesaikan maslah dapat dilakukan langkah langkah sebagai berikut ( Clark and Wright 1994 ).

1. Mendaftar jumlah kapasitas maksimum kendaraan yang tersedia dan alokasi kendaraan yang digunakan untuk pengiriman ke custemen, mengasumsikan bahwa setiap node permintaan pada rute awal dipenuhi secara individual

2. Memebuat matriks jarak yaitu jarak antera depot dengan node dan jarak anatr node. Pengukuran jarak dari node A ke B sama dengan jarak dari node B ke A sehingga matriks jarak ini termasuk matriks symmetric

Tabel 1. Bentuk Umum Matriks Jarak

\begin{tabular}{|c|c|c|c|c|c|c|c|}
\hline & $\mathrm{P}_{0}$ & & & & & & \\
\hline $\mathrm{P}_{0}$ & 0 & $\mathrm{P}_{1}$ & & & & & \\
\hline $\mathrm{P}_{1}$ & & 0 & $\mathrm{P}_{\mathrm{i}}$ & & & & \\
\hline $\mathrm{P}_{\mathrm{i}}$ & $\mathrm{C}_{\mathrm{oi}}$ & & 0 & $\ldots$ & & & \\
\hline$\ldots$ & & & & 0 & $\mathrm{P}_{\mathrm{j}}$ & & \\
\hline $\mathrm{P}_{\mathrm{j}}$ & & & $\mathrm{C}_{\mathrm{ij}}$ & & 0 & $\ldots$ & \\
\hline$\ldots$ & & & & & & 0 & $\mathrm{P}_{\mathrm{n}}$ \\
\hline $\mathrm{P}_{\mathrm{n}}$ & & & & & & & 0 \\
\hline
\end{tabular}

Dimana :

$$
\begin{aligned}
& \mathrm{P} 0=\text { depot } \\
& \mathrm{Pi}=\text { node ke } \mathrm{i} \\
& \mathrm{Pj}=\text { node ke } \mathrm{j} \\
& \mathrm{Coi}=\text { jarak dari depot ke node } \mathrm{i}=\text { jarak dari node } \mathrm{i} \text { ke depot } \\
& \mathrm{Cij}=\text { jarak dari node } i \text { ke node } j=\text { jarak dari node } j \text { ke node } i
\end{aligned}
$$

3. Menghitung nilai penghematan $(S i . j)$ berupa jarak tempuh dari suatu kendaraan yang menggantikan dua kendaraan untuk melayani node $i$ dan $j$.

Si..j=Coi+Coj-Cij.

$C o i=$ jarak dari depot ke node $i C i j=$ jarak dari node $i$ ke node $j$

$S i j=$ nilai penghematan jarak dari node $i$ ke node $j$

Nilai penghematan $(S i . . j)$ adalah jarak yang dapat dihemat jika rute $o-i-o$ digabungkan dengan rute $o-j-o$ menjadi rute tunggal $o-i-j-o$ yang dilayani oleh satu kendaraan yang sama.

4. Membuat matriks penghematan, dimana bentuk umum dari matriks penghematan yang dikembangkan oleh Clarke dan Wright dapat dilihat pada tabel 2.

Tabel 2. Bentuk Umum Matriks Penghematan

\begin{tabular}{|l|l|l|l|l|l|l|l|}
\hline Q & $\mathrm{P}_{0}$ & & & & & & \\
\hline & 0 & $\mathrm{P}_{1}$ & & & & & \\
\hline & & 0 & $\mathrm{Pi}_{1}$ & & & & \\
\hline$\ldots$ & Coi & & 0 & $\ldots$ & & & \\
\hline
\end{tabular}


Tabel 2. Bentuk Umum Matriks Penghematan (lanjutan)

\begin{tabular}{|l|l|l|l|l|l|l|l|}
\hline $\mathrm{q}_{\mathrm{i}}$ & & & $\mathrm{t}_{\mathrm{ij}}$ & 0 & $\mathrm{P}_{\mathrm{j}}$ & & \\
\hline & & & $\mathrm{S}$ ij & & & & \\
\hline $\mathrm{q}_{\mathrm{j}}$ & & & & & 0 & $\cdots$ & \\
\hline$\ldots$ & & & & & & 0 & $\mathrm{Pn}_{\mathrm{n}}$ \\
\hline $\mathrm{qn}$ & & & & & & & 0 \\
\hline
\end{tabular}

Dimana:

$q i=$ permintaan node ke- $i$

$q j=$ permintaan node ke- $j$

$P o=$ depot

$P i=$ node ke $i$

$P j=$ node ke $j$

$S i j=$ nilai penghematan jarak dari node $i$ ke node $j$

Nilai-nilai dalam tij menentukan apakah kombinasi $P i$ dengan $P j$ berada dalam satu rute. Petunjuk ini mempunyai nilai-nilai berikut: $t i j=0$, jika node tidak dihubungkan oleh satu rute kendaraan 1, jika dua node dihubungkan pada satu rute kendaraan 2, jika node dilayani tersendiri oleh satu kendaraan Pemasukan (entries) tij tidak ditunjukkan dalam matriks penghematan, pada awalnya tetapkan $t i j=2$, yang berarti bahwa satu kendaraan dipakai untuk melayani masing-masing node.

Pada tahap ini proses berulang itu digerakkan sampai masing-masing matriks penghematan itu dievaluasi untuk perbaikan rute lebih lanjut. Prosedur ini adalah untuk mencari penghematan terbesar dari matriks itu berdasarkan kondisi yang berikut untuk setiap sel $(i, j)$ :

a. $t i, o$ dan $t j, o=0$

b. $\quad P i$ dan $P j$ belum dialokasikan pada jalur kendaraan yang sama

c. Memperbaiki matriks penghematan, dengan memindahkan kendaraan-kendaraan yang dialokasikan pada muatan $q i$ dan $q j$ serta menambah sebuah kendaraan untuk menutup muatan $q i$ dan $q j$ tidaklah menyebabkan kendaraan-kendaraan yang tersedia dalam setiap kolom dari matriks penghematan

5. Memilih sebuah sel dimana 2 rute yang dapat dikombinasikan menjadi satu rute tunggal. Sebuah nilai dari $t i, j=1$ ditempatkan dalam sel itu, dan semua nilai $t i, j$ disesuaikan sedemikian rupa sehingga jumlah $t i, j$ sepanjang suatu baris dan $t i, j$ ke bawah kolom dimana $i$ $=j$, adalah selalu sama dengan 2. Apabila $t j, o=0$, pasanglah $q j=0$ dan buatlah $q j$ sama dengan total muatan pada rute itu untuk semua $j$ yang lain. Prosedur ini berakhir apabila tidak ada lagi kemungkinan konsolidasi lebih lanjut.

\section{HASIL DAN PEMBAHASAN}

\section{- Data Permintaan}

Data lokasi outlet satu salesmen rute konvensional yang terdiri dari dan mayoritas toko-toko bangunan sekitar sepele (serang pandeglang lebak), lokasi proyek 
Tabel 3. Daftar Customer X

\begin{tabular}{|c|l|c|}
\hline NO & \multicolumn{1}{|c|}{ NAMA TOKO } & ALAMAT \\
\hline 1 & $\begin{array}{l}\text { APUT H, BPK } \\
\text { (ORD.TK.SINAR H) }\end{array}$ & CIOMAS SERANG \\
\hline 2 & ELI. H, TK (PANDEGLANG) & CIOMAS SERANG \\
\hline 3 & ELITA JAYA MANDIRI TB. & SERANG \\
\hline 4 & $\begin{array}{l}\text { SARBINI BP./SD } \\
\text { KADUBERUM 2 }\end{array}$ & PABUARAN SERANG \\
\hline 5 & $\begin{array}{l}\text { GOTONG ROYONG TB. } \\
\text { BAROS SERANG }\end{array}$ \\
\hline 6 & $\begin{array}{l}\text { MADANI PUTRA SALUYU } \\
\text { TB. }\end{array}$ & $\begin{array}{l}\text { FAJAR PEMBANGUNAN } \\
\text { TB. }\end{array}$ \\
\hline
\end{tabular}

Tabel 4. Daftar Customer X

\begin{tabular}{|c|l|l|}
\hline NO & \multicolumn{1}{|c|}{ ALAMAT GUDANG } & DAERAH \\
\hline 1 & $\begin{array}{l}\text { JL.JAMAL MAYOR ALIM } \\
\text { NO.14 }\end{array}$ & RANGKAS BITUNG \\
\hline 2 & $\begin{array}{l}\text { JL.RAYA TERMINAL } \\
\text { MANDALA }\end{array}$ & RANGKAS BITUNG \\
\hline 3 & TERMINAL MANDALA & RANGKAS BITUNG \\
\hline 4 & $\begin{array}{l}\text { JL.RUKO MANDALA 9-10 } \\
\text { NO:SUNAN KALI JAGA }\end{array}$ & RANGKAS BITUNG \\
\hline 6 & JL.IR H.JUANDA NO 152 & RANGKAS BITUNG \\
\hline 7 & JL. SUNAN KALIJAGA & RANGKAS BITUNG \\
\hline 8 & $\begin{array}{l}\text { JL.TERMINAL NENGGOR } \\
\text { TANJUNG }\end{array}$ & RANGKAS BITUNG \\
\hline 9 & $\begin{array}{l}\text { JL.TIRTAYASA NO 50 } \\
\text { WARUNG }\end{array}$ & RANGKAS BITUNG \\
\hline 5
\end{tabular}


Tabel 5. Daftar Customer X

\begin{tabular}{|c|l|c|}
\hline NO & \multicolumn{1}{|c|}{ ALAMAT GUDANG } & DAERAH \\
\hline 1 & JL. RAYA JOHA NO 56 & LABUAN \\
\hline 2 & JL. JENDARAL SUDIRMAN 324 & LABUAN \\
\hline 3 & $\begin{array}{l}\text { JL. LABUAN KM 5 KADU } \\
\text { ONCONG }\end{array}$ & LABUAN \\
\hline 4 & JL. RAYA SUDIRMAN & LABUAN \\
\hline 5 & $\begin{array}{l}\text { JL. RAYA LABUAN } \\
\text { PANDEGLANG }\end{array}$ & LABAUN \\
\hline 6 & JL. RAYA CARITA PANDEGLANG & LABUAN \\
\hline 7 & JL. RAYA LABUAN KM 17 & LABUAN \\
\hline 8 & $\begin{array}{l}\text { JL. SUYANA PASAR } \\
\text { PANDEGLANG }\end{array}$ & LABUAN \\
\hline 9 & JL.RAYA CARINGIN & LABUAN \\
\hline 10 & LABUAN CIKEDAL & LABUAN \\
\hline
\end{tabular}

\section{Rute hari Senin}

PT X menggunakan 1 truk untuk pengiriman semen $50 \mathrm{~kg}$ dengan kapasitas angkut maksimum 560 sak. Selanjutnya akan dibuat matriks jarak yang entri-entrinya adalah jarak antara depot (agen) dengan pangkalan (node) dan antar pangkalan (node).

Tabel 6. Matriks Jarak

\begin{tabular}{|c|c|c|c|c|c|c|c|}
\hline & 1 & 2 & 3 & 4 & 5 & 6 & 7 \\
\hline 0 & 30 & 38 & 42 & 45 & 58 & 52 & 56 \\
\hline 1 & 0 & & & & & & \\
\hline 2 & 4,9 & 0 & & & & & \\
\hline 3 & 15 & 5,5 & 0 & & & & \\
\hline 4 & 11 & 13 & 12 & 0 & & & \\
\hline 5 & 22 & 19 & 18 & 6,6 & 0 & & \\
\hline 6 & 28 & 25 & 24 & 12 & 6,1 & 0 & \\
\hline 7 & 25 & 19 & 22 & 10 & 6,7 & 8,7 & 0 \\
\hline
\end{tabular}

Berdasarkan Persamaan akan dibuat matriks penghematan. Berikut ini adalah salah satu contoh perhitungan nilai penghematan untuk pangkalan, dengan menggunakan Persamaan, dimasukkan nilai jarak, maka didapatkan nilai penghematan. 
Tabel 7 Matriks Penghematan (km)

\begin{tabular}{|c|c|c|c|c|c|c|c|}
\hline & 1 & 2 & 3 & 4 & 5 & 6 & 7 \\
\hline 0 & 30 & 38 & 42 & 45 & 58 & 52 & 56 \\
\hline 1 & 0 & & & & & & \\
\hline 2 & 4,9 & 0 & & & & & \\
\hline 3 & 15 & 5,5 & 0 & & & & \\
\hline 4 & 11 & 13 & 12 & 0 & & & \\
\hline 5 & 22 & 19 & 18 & 6,6 & 0 & & \\
\hline 6 & 28 & 25 & 24 & 12 & 6,1 & 0 & \\
\hline 7 & 25 & 19 & 22 & 10 & 6,7 & 8,7 & 0 \\
\hline
\end{tabular}

$\mathrm{S} 12=\mathrm{C} 10+\mathrm{C} 02-\mathrm{C} 12=30+38-4,9=63,1$

Menggunakan cara yang sama, diperoleh matriks penghematan untuk semua node disajikan pada Tabel Total jarak : $30+30+38+38+42+42+45++58+58+52+52+56+56=642$

Setelah matriks penghematan terbentuk, selanjutnya menentukan kelompok rute berdasarkan nilai penghematan yang terbesar sampai yang terkecil dari matriks penghematan. Langkah ini merupakan iterasi dari matriks penghematan, dimana jika nilai penghematan terbesar tedapat pada node $i$ dan $j$ maka baris $i$ dan kolom $j$ dicoret, lalu $i$ dan $j$ digabungkan dalam satu kelompok rute, demikian seterusnya sampai iterasi yang terakhir. Selanjutnya pengelompokkan rute berdasarkan nilai penghematan diperoleh dari node gabungan hasil iterasi matriks penghematan. Kemudian mengurutkan daftar tujuan / pelanggan sesuai dengan kelompok rute yang berdasarkan nilai penghematan tersebut.

Langkah-langkah untuk pembentukan kelompok rute:

a. Memilih nilai penghematan terbesar dalam matriks penghematan, yaitu 107 antara node 7 dan node 5. Mengabungkan keduanya menjadi satu rute, kemudian mencoret semua baris pada kolom 7 dan mencoret semua kolom pada baris 5 . Rute yang terbentuk adalah : Rute $1=$ 7 - 5 . Untuk rute ini semen $50 \mathrm{~kg}$ yang dikirim adalah $50+30=80$ semen, dan masih belum melampaui kapasitas dari kendaraan yaitu 560. Pengelompokan ini disajikan pada Tabel Iterasi 1 di bawah ini:

Tabel 8 Iterasi 1

\begin{tabular}{|c|c|c|c|c|c|c|c|}
\hline & 1 & 2 & 3 & 4 & 5 & 6 & 7 \\
\hline 0 & 30 & 38 & 42 & 45 & 58 & 52 & 56 \\
\hline 1 & 0 & & & & & & \\
\hline 2 & 57 & 0 & & & & & \\
\hline 3 & 75 & 74,5 & 0 & & & & \\
\hline 4 & 64 & 70 & 75 & 0 & & & \\
\hline 5 & 66 & 77 & 82 & 96 & 0 & & \\
\hline 6 & 54 & 65 & 70 & 85 & 104 & 0 & \\
\hline 7 & 61 & 75 & 76 & 91 & 107 & 99 & 0 \\
\hline
\end{tabular}

b. Memilih nilai penghematan terbesar dalam matriks penghematan, yaitu 104 antara node 7 dan node 5. Mengabungkan node 7 dan node 1 menjadi satu rute dalam rute 2, karena jika digabungkan dengan rute 1 melebihi kapasitas angkut dari kendaraan, kemudian mencoret semua kolom pada baris 1 dan mencoret semua baris pada kolom 7. Rute yang terbentuk adalah: Rute $1=7-5-1$. Untuk rute ini tabung yang dikirim adalah $50+30+50=130$ tabung. Belum melampaui kapasitas. Pengelompokan ini disajikan pada Tabel Iterasi 2. 
Tabel 9 Iterasi 2

\begin{tabular}{|c|c|c|c|c|c|c|c|}
\hline & 1 & 2 & 3 & 4 & 5 & 6 & 7 \\
\hline 0 & 30 & 38 & 42 & 45 & 58 & 52 & 56 \\
\hline 1 & 0 & & & & & & \\
\hline 2 & 57 & 0 & & & & & \\
\hline 3 & 75 & 74,5 & 0 & & & & \\
\hline 4 & 64 & 70 & 75 & 0 & & & \\
\hline 5 & 66 & 77 & 82 & 96 & 0 & & \\
\hline 6 & 54 & 65 & 70 & 85 & 104 & 0 & \\
\hline 7 & 61 & 75 & 76 & 91 & 107 & 99 & 0 \\
\hline
\end{tabular}

\section{Rute hari senin}

Selanjutnya akan dihitung biaya bahan bakar untuk setiap rute. Jika diasumsikan biaya transportasi adalah biaya bahan bakar solar kendaraan yaitu 1 liter/Rp. 7.600/8 km, maka rute dan biaya pada hari Senin disajikan pada Tabel 10.

Tabel 10 Rute dan biaya pada hari Senin

\begin{tabular}{|c|l|}
\hline & \multicolumn{1}{|c|}{ RUTE 1 } \\
\hline & GUDANG; \\
& - JL. RAYA PANGLIMA \\
& POLDA LINGKUNGAN PK3B , \\
& SERANG - KP. PASAR \\
& SINGGAR RT.15 RW.03 DESA \\
& SUKALAKSANA J1. RAYA PETIR \\
& CURUG KM.4, CURUG \\
Dengan & JL.RAYA SERANG PANDEGLANG \\
menggunakan & KP NYATUH KP. CIPATAT CIOMAS \\
Clarke and wright & PABUARAN \\
savings & JL. RAYA PS. CIOMAS SERANG \\
& (ORD: TK. SINAR HARAPAN) - \\
& JL.RAYACIOMAS - UJUNGTEBU \\
& PANDEGLANG,42164 - JL.RAYA \\
& CIOMAS KP CISAAT \\
& PADARINCANG CIOMAS \\
\hline Jrak tempuh & R21 KM \\
\hline Biayaya & \\
\hline Trasportasi & \\
\hline
\end{tabular}


2. Rute Hari Selasa

Tabel 11. Matriks Jarak asal-tujuan pada hari Selasa

3.

\begin{tabular}{|r|c|c|c|c|c|c|c|c|c|c|}
\hline & 1 & 2 & 3 & 4 & 5 & 6 & 7 & 8 & 9 & 10 \\
\hline 0 & 30 & 58 & 34 & 35 & 33 & 34 & 33 & 34 & 53 & 45 \\
\hline 1 & 0 & & & & & & & & & \\
\hline 2 & 28 & 0 & & & & & & & & \\
\hline 3 & 2,8 & 23 & 0 & & & & & & & \\
\hline 4 & 4,4 & 23 & 37 & 0 & & & & & & \\
\hline 5 & 2,2 & 26 & 0,55 & 38 & 0 & & & & & \\
\hline 6 & 2,9 & 27 & 1,5 & 38 & 0,9 & 0 & & & & \\
\hline 7 & 2,2 & 26 & 0,55 & 38 & 0 & 0,9 & 0 & & & \\
\hline 8 & 2,9 & 17 & 0,27 & 37 & 0,7 & 1,1 & 0,7 & 0 & & \\
\hline 9 & 19 & 17 & 17 & 25 & 18 & 18 & 18 & 17 & 0 & \\
\hline 10 & 129 & 16 & 11 & 32 & 11 & 11 & 11 & 10 & 32 & 0 \\
\hline
\end{tabular}

Tabel 12. Matriks penghematan pada hari Selasa

\begin{tabular}{|c|c|c|c|c|c|c|c|c|c|c|}
\hline & 1 & 2 & 3 & 4 & 5 & 6 & 7 & 8 & 9 & 10 \\
\hline 0 & 31 & 58 & 34 & 35 & 33 & 34 & 33 & 34 & 53 & 45 \\
\hline 1 & 0 & & & & & & & & & \\
\hline 2 & 61 & 0 & & & & & & & & \\
\hline 3 & 62,2 & 69 & 0 & & & & & & & \\
\hline 4 & 61,6 & 70 & 32 & 0 & & & & & & \\
\hline 5 & 61,8 & 65 & 67 & 30 & 0 & & & & & \\
\hline 6 & 62,1 & 65 & 66,5 & 31 & 66,1 & 0 & & & & \\
\hline 7 & 61,8 & 65 & 67 & 30 & 66 & 66,1 & 0 & & & \\
\hline 8 & 61,1 & 66 & 68 & 32 & 66,3 & 67 & 66,3 & 0 & & \\
\hline 9 & 65 & 94 & 70 & 63 & 75 & 69 & 68 & 70 & 0 & \\
\hline 10 & 64 & 84 & 68 & 48 & 66 & 68 & 67 & 69 & 66 & 0 \\
\hline
\end{tabular}

langkah- langkah untuk menentukan node penghematan, yaitu sebagai berikut:

a. Memilih nilai penghematan terbesar dalam matriks penghematan, yaitu 94 antara node 2 dan node 9. Mengabungkan keduanya menjadi satu rute, kemudian mencoret semua baris pada kolom 2 dan mencoret semua kolom pada baris 9. Rute yang terbentuk adalah: Rute $1=9$ - 2 . Untuk rute ini semen $40 \mathrm{~kg}$ yang dikirim adalah $60+50=120$ semen, dan masih belum melampaui kapasitas dari kendaraan yaitu 560. Pengelompokan ini disajikan pada Tabel 13 Iterasi 1.

Tabel 13. Ierasi 1

\begin{tabular}{|r|c|c|c|c|c|c|c|c|c|c|}
\hline & 1 & 2 & 3 & 4 & 5 & 6 & 7 & 8 & 9 & 10 \\
\hline 0 & 31 & 58 & 34 & 35 & 33 & 34 & 33 & 34 & 53 & 45 \\
\hline 1 & 0 & & & & & & & & & \\
\hline 2 & 61 & 0 & & & & & & & & \\
\hline 3 & 62,2 & 69 & 0 & & & & & & & \\
\hline 4 & 61,6 & 70 & 32 & 0 & & & & & & \\
\hline 5 & 61,8 & 65 & 67 & 30 & 0 & & & & & \\
\hline 6 & 62,1 & 65 & 66,5 & 31 & 66,1 & 0 & & & & \\
\hline 7 & 61,8 & 65 & 67 & 30 & 66 & 66,1 & 0 & & & \\
\hline 8 & 61,1 & 66 & 68 & 32 & 66,3 & 67 & 66,3 & 0 & & \\
\hline 9 & 65 & 94 & 70 & 63 & 75 & 69 & 68 & 70 & 0 & \\
\hline 10 & 64 & 84 & 68 & 48 & 66 & 68 & 67 & 69 & 66 & 0 \\
\hline
\end{tabular}


b. Memilih nilai penghematan terbesar selanjutnya dalam matriks penghematan, yaitu 84 antara node 2 dan node 10 . Mengabungkan keduanya menjadi satu rute, kemudian mencoret semua baris pada kolom 10 dan mencoret semua kolom pada baris 17 . Rute yang terbentuk adalah : Rute $1=9-2-10$. Untuk rute ini semen $40 \mathrm{~kg}$ yang dikirim adalah $60+50+80=$ 190 semen, dan masih belum melampaui kapasitas dari kendaraan yaitu 560. Pengelompokan ini disajikan pada Tabel 14. Iterasi 2

Tabel 14. Iterasi 2 Pengelompokan Matriks Penghematan

\begin{tabular}{|c|c|c|c|c|c|c|c|c|c|c|}
\hline & 1 & 2 & 3 & 4 & 5 & 6 & 7 & 8 & 9 & 10 \\
\hline 0 & 31 & 58 & 34 & 35 & 33 & 34 & 33 & 34 & 53 & 45 \\
\hline 1 & 0 & & & & & & & & & \\
\hline 2 & 61 & 0 & & & & & & & & \\
\hline 3 & 62,2 & 69 & 0 & & & & & & & \\
\hline 4 & 61,6 & 70 & 32 & 0 & & & & & & \\
\hline 5 & 61,8 & 65 & 67 & 30 & 0 & & & & & \\
\hline 6 & 62,1 & 65 & 66,5 & 31 & 66,1 & 0 & & & & \\
\hline 7 & 61,8 & 65 & 67 & 30 & 66 & 66,1 & 0 & & & \\
\hline 8 & 61,1 & 66 & 68 & 32 & 66,3 & 67 & 66,3 & 0 & & \\
\hline 9 & 65 & 94 & 70 & 63 & 75 & 69 & 68 & 70 & 0 & \\
\hline 10 & 64 & 84 & 68 & 48 & 66 & 68 & 67 & 69 & 66 & 0 \\
\hline
\end{tabular}

c. Memilih nilai terbesar berikutnya dalam matrik penghematan, kemudian melakukan langkah seperti pada iterasi 1 dan 2, apabila sudah melebihi kapasitas maka membuat rute baru. sebagai berikut:

Rute 1: $0-1-4-3-8-9$

$100+59+80+80+60=379$

Rute 2: $0-5-6-7-10-2$

$60+70+80+150+50=410$

Selanjutnya akan dihitung biaya bahan bakar untuk setiap rute. Dari hasil pengolahan a c (lihat lampiran 2), maka diperoleh 2 rute untuk semen 40kg dari depot (PT. Bcs Logistik) ke pelanggan menggunakan algoritma Clarke and Wright Savings. Rute dan biaya pada hari Selasa disajikan pada Tabel 15.

Tabel 5. Rute dan Biaya pada hari Selasa

\begin{tabular}{|c|c|c|}
\hline & RUTE 1 & RUTE 2 \\
\hline $\begin{array}{l}\text { Dengan menggunakan Clarkle and } \\
\text { wright saving }\end{array}$ & \begin{tabular}{|cl} 
GUDANG: \\
- & JL MAYOR JAMAL ALIM \\
& NO. 04 \\
& RANGKASBITUNG \\
- & JLN RUKO MANDALA 9- \\
& 10 RANGKASBITUNG \\
- & TERMINAL MANDALA \\
& RANGKAS BITUNG \\
- & JLN. TIRTAYASA NO.50 \\
& RANGKASBITUNG \\
- JL.TERMINAL NENGGOR & TANJUNG REJA \\
& PANDEGLANG
\end{tabular} & $\begin{array}{cl}\text { GUDANG: } \\
- & \text { JL.SUNAN KALIJAGA NO:149 } \\
& \text { RANGKAS BITUNG } \\
- & \text { JL.IR H.JUANDA NO.152 } \\
& \text { RANGKASBITUNG } \\
- & \text { JL.SUNAN KALIJAGA } \\
& \text { RANGKAS BITUNG SERANG } \\
- & \text { JL. KAMPUNG SAMPAY } \\
\text { - } & \text { WARUNG GUNUNG } \\
\text { JL.RAYA TERMINAL } \\
\text { MANDALA RANGKAS } \\
\text { BITUNG }\end{array}$ \\
\hline Jarak tempuh & $193 \mathrm{KM}$ & $203 \mathrm{KM}$ \\
\hline Biaya Trasportasi & Rp 370,000 & Rp 370,000 \\
\hline
\end{tabular}


3. Rute hari Rabu

Tabel 16 Matriks Jarak asal-tujuan $(\mathrm{km})$

\begin{tabular}{|c|c|c|c|c|c|c|c|c|c|c|}
\hline & 1 & 2 & 3 & 4 & 5 & 6 & 7 & 8 & 9 & 10 \\
\hline 0 & 92 & 88 & 92 & 91 & 58 & 77 & 99 & 77 & 81 & 88 \\
\hline 1 & 0 & & & & & & & & & \\
\hline 2 & 44 & 0 & & & & & & & & \\
\hline 3 & 52 & 8,8 & 0 & & & & & & & \\
\hline 4 & 45 & 0,60 & 8,2 & 0 & & & & & & \\
\hline 5 & 54 & 35 & 33 & 34 & 0 & & & & & \\
\hline 6 & 60 & 17 & 16 & 16 & 23 & 0 & & & & \\
\hline 7 & 33 & 11 & 19 & 12 & 42 & 27 & 0 & & & \\
\hline 8 & 60 & 17 & 16 & 16 & 23 & 17 & 27 & 0 & & \\
\hline 9 & 40 & 11 & 12 & 12 & 35 & 27 & 6,7 & 27 & 0 & \\
\hline 10 & 55 & 1,8 & 10 & 2,8 & 41 & 18 & 10 & 18 & 3,7 & 0 \\
\hline
\end{tabular}

Tabel 17 Matriks Penghematan

\begin{tabular}{|c|c|c|c|c|c|c|c|c|c|c|}
\hline & 1 & 2 & 3 & 4 & 5 & 6 & 7 & 8 & 9 & 10 \\
\hline 0 & 92 & 88 & 92 & 91 & 58 & 77 & 99 & 77 & 81 & 88 \\
\hline 1 & 0 & & & & & & & & & \\
\hline 2 & 136 & 0 & & & & & & & & \\
\hline 3 & 132 & 171 & 0 & & & & & & & \\
\hline 4 & 128 & 178 & 174 & 0 & & & & & & \\
\hline 5 & 96 & 111 & 117 & 115 & 0 & & & & & \\
\hline 6 & 109 & 148 & 153 & 152 & 112 & 0 & & & & \\
\hline 7 & 158 & 176 & 172 & 178 & 115 & 149 & 0 & & & \\
\hline 8 & 109 & 148 & 153 & 152 & 112 & 153 & 154 & 0 & & \\
\hline 9 & 133 & 158 & 161 & 160 & 104 & 131 & 173 & 131 & 0 & \\
\hline 10 & 125 & 174 & 170 & 176 & 105 & 147 & 177 & 177 & 165 & 0 \\
\hline
\end{tabular}

Langkah- langkah untuk menentukan node penghematan, yaitu sebagai berikut:

a. Memilih nilai penghematan terbesar dalam matriks penghematan, yaitu 178 antara node 4 dan node 7. Mengabungkan keduanya menjadi satu rute, kemudian mencoret semua baris pada kolom 4 dan mencoret semua kolom pada baris 7 . Rute yang terbentuk adalah: Rute $1=$ $4-7$. Untuk rute ini semen $40 \mathrm{~kg}$ yang dikirim adalah $50+60=110$ semen, dan masih belum melampaui kapasitas dari kendaraan yaitu 560. Pengelompokan ini disajikan pada Tabel 18 Iterasi 1.

Tabel 18 Iterasi 1 Pengelompokan Matriks Penghematan

\begin{tabular}{|c|c|c|c|c|c|c|c|c|c|c|}
\hline & 1 & 2 & 3 & 4 & 5 & 6 & 7 & 8 & 9 & 10 \\
\hline 0 & 92 & 88 & 92 & 91 & 58 & 77 & 99 & 77 & 81 & 88 \\
\hline 1 & 0 & & & & & & & & & \\
\hline 2 & 136 & 0 & & & & & & & & \\
\hline 3 & 132 & 171 & 0 & & & & & & & \\
\hline
\end{tabular}




\begin{tabular}{|c|c|c|c|c|c|c|c|c|c|c|}
\hline 4 & 128 & 170 & 174 & 0 & & & & & & \\
\hline 5 & 96 & 111 & 117 & 115 & 0 & & & & & \\
\hline
\end{tabular}

Tabel 18 Iterasi 1 Pengelompokan Matriks Penghematan (lanjutan)

\begin{tabular}{|c|c|c|c|c|c|c|c|c|c|c|}
\hline 6 & 109 & 148 & 153 & 152 & 112 & 0 & & & & \\
\hline 7 & 158 & 176 & 172 & 178 & 115 & 149 & 0 & & & \\
\hline 8 & 109 & 148 & 153 & 152 & 112 & 153 & 154 & 0 & & \\
\hline 9 & 133 & 158 & 161 & 160 & 104 & 131 & 173 & 131 & 0 & \\
\hline 10 & 125 & 174 & 170 & 176 & 105 & 147 & 177 & 176 & 165 & 0 \\
\hline
\end{tabular}

b. Memilih nilai penghematan terbesar selanjutnya dalam matriks penghematan, yaitu 177 antara node 7 dan node 10. Mengabungkan keduanya menjadi satu rute, kemudian mencoret semua baris pada kolom 10 dan mencoret semua kolom pada baris 7 . Rute yang terbentuk adalah: Rute $1=4-7-10$. Untuk rute ini tabung semen $40 \mathrm{~kg}$ yang dikirim adalah $50+60+$ $75=185$ semen, dan masih belummelampaui kapasitas dari kendaraan yaitu 560 . Pengelompokan ini disajikan pada Tabel 19 Iterasi 2.

Tabel 19 Iterasi 2 Matriks Penghematan

\begin{tabular}{|c|c|c|c|c|c|c|c|c|c|c|}
\hline & 1 & 2 & 3 & 4 & 5 & 6 & 7 & 8 & 9 & 10 \\
\hline 0 & 92 & 88 & 92 & 91 & 58 & 77 & 99 & 77 & 81 & 88 \\
\hline 1 & 0 & & & & & & & & & \\
\hline 2 & 136 & 0 & & & & & & & & \\
\hline 3 & 132 & 171 & 0 & & & & & & & \\
\hline 4 & 128 & 170 & 174 & 0 & & & & & & \\
\hline 5 & 96 & 111 & 117 & 115 & 0 & & & & & \\
\hline 6 & 109 & 148 & 153 & 152 & 112 & 0 & & & & \\
\hline 7 & 158 & 176 & 172 & 178 & 115 & 149 & 0 & & & \\
\hline 8 & 109 & 148 & 153 & 152 & 112 & 153 & 154 & 0 & & \\
\hline 9 & 133 & 158 & 161 & 160 & 104 & 131 & 173 & 131 & 0 & \\
\hline 10 & 125 & 174 & 170 & 176 & 105 & 147 & 177 & 176 & 165 & 0 \\
\hline
\end{tabular}

c. Memilih nilai terbesar berikutnya dalam matrik penghematan, kemudian melakukan langkah seperti pada iterasi 1 dan 2, apabila sudah melebihi kapasitas maka membuat rute baru.

Rute $1: 0-5-8-2-4-1$

$58+77+88+91+92=406$

Rute $2: 0-6-9-10-3-7$

$77+81+88+91+92+99=437$

Selanjutnya akan dihitung biaya bahan bakar untuk setiap rute. Dari hasil pengolahan a - c, maka diperoleh 1 rute untuk mendistribusikan semen $40 \mathrm{~kg}$ dari depot (PT.Bcs Logistik) ke pelanggan menggunakan rute sebagai berikut.

Tabel 20 Rute dan Biaya pada hari Rabu

\begin{tabular}{l|r} 
RUTE 1 & RUTE 2
\end{tabular}




\begin{tabular}{|c|c|c|}
\hline $\begin{array}{l}\text { Dengan } \\
\text { menggunakan } \\
\text { Clarkle and } \\
\text { wright saving }\end{array}$ & $\begin{array}{ll}- & \text { JL. RAYA SUDIRMAN LABUAN } \\
- & \text { JL. RAYA LABUAN KM 17 SONDONG } \\
\text { - } & \text { LABUAN } \\
\text { - } & \text { JL. JENDRAL SUDIRMAN 324 LABUAN } \\
& \text { JL. RAYA L;ABUAN KM 5 KADU } \\
\text { - } & \text { ONCONG LABUAN } \\
\text { JL. RAYA JAHA NO 56 LABUAN }\end{array}$ & $\begin{array}{ll}- & \text { JL. RAYA LABUAN } \\
& \text { PANDEGLANG } \\
- & \text { JL. RAYA CARINGIUN } \\
& \text { LABUAN } \\
- & \text { JL. LABUAN KENDAL } \\
- & \text { JL. SUYANA PASAR } \\
& \text { PANDEGLANG } \\
- & \text { JL. CARITA PANDEGLANG }\end{array}$ \\
\hline Jarak tempuh & $406 \mathrm{KM}$ & $437 \mathrm{KM}$ \\
\hline Biaya Trasportasi & Rp 560,000 & Rp 600,000 \\
\hline
\end{tabular}

\section{KESIMPULAN}

1. Dalam penelitian ini perusahaan menumpulkan DO terlebih dahulu, setiap DO atau permintaan di pilih-pilih dengan satu wilayah agar rute kita pilih jarak terdekat dari gudang ke toko 1 dan dari toko 1 ke toko 2 dan seterusnya hingga balik kembali ke gudang.

2. Sub rute dari gudang cikande ke daerah toko-toko yang ada Serang yang di rencanakan menghemat jarak $321 \mathrm{~km}$, dan sub rute daerah gudang ke toko-toko sekitar Rangkas Bitung $178 \mathrm{~km}$, dan terakhir.

\section{SARAN}

Dengan hasil penelitian ini disarankan PT. BCS LOGISTIK bisa mempertimbangkan untuk menggunakan penyelesaian Capacitated Vehicle Routing Problem (CVRP) dengan menggunakan algoritma Clarke and Wright Savings sehingga dapat lebih menghemat waktu dan biaya..

\section{DAFTAR PUSTAKA}

Agus Purnomo. (2010). Penentuan Rute Pengiriman dan Biaya Transportasi dengan Menggunakan Metode Clarke and Wright Saving Heuristik (Studi Kasus di PT Teh Botol Sosro Bandung). Jurnal Logistik Bisnis Politeknik Pos Indinesia, Vol 1, No. 2, 97-117.

Anita Christine sembiring. (2008). Penentuan Rute Distribusi Produk yang OptimaL dengan Menggunakan Algoritma Heuristik pada PT. Coca-cola Bottling Indonesia Medan. Jurnal Managemen Teknologi 01/2002;5 Ayu S daN Abusini S. (2008). Implementasi model Capacitated Vehicle Routing Problem pada pengiriman pupuk urea bersubsidi (Studi Kasus CV. Adi Chandra Sumekar, Sumenep). Jurnal Mahasiswa Matematika universitas brawijaya Malang

Clarke, G. \& Wright, J.W. (1964). Scheduling of Vehicles from a Central Depot to a Number of Delivery Points, Operations Research, Vol. 12, No. 4, 568-581.

Joseph Christian S.(2011). Analisis Sistem Pengangkutan Sampah Kota Makassar dengan Metode Penyelesaian Vehicle Routing Problem(VRP).Jurnal Sampah Kota Makassar.

Octara, Lita (2013). Pembentukan Rute Distribusi Menggunakan Algoritma Clarke \& Wright Savings dan Algoritma Sequential Insertion. Jurnal online Institut teknoligi Nasional Bandung, Indonesia Vol 2, No 2

Pichpibula, T and Kawtummachai, R. (2012). An improved Clarke and Wright savings $\backslash$ algorithm for the capacitated vehicle routing problem. ScienceAsia 38 (2012): 307-318

Solomon, M. (1987). Algorithms for the Vehicle Routing and Scheduling Problems withTime Windows Constraints.Operations Research, Vol. 35, No. 2, 254-265.

Google Maps, [Online, diakses pada tanggal 20 AGUSTUS 2018] dari https://maps.google.com/maps?hl =en (http://www.artikelsiana.com /2014/11) 
